\title{
Status Keluarga Sebagai Subyek Hukum dalam Pengurusan Harta Bersama
}

\author{
Perwitiningsih dan Rikardo Simarmata \\ witinis@gmail.com \\ Universitas Gadjah Mada
}

\begin{abstract}
Keywords: $\quad$ Abstract
Family; Legal This research is aimed at analyzing family status as legal subjects i.e. rights, wether Subjects; Marital husband and wife are considered as a legal subject or an independent individual subject. The Assets. discussion of this research is focused on the family as the legal subject in the management of joint assets. This research concludes that the family is one legal subject as member of marital assets. In law inforcement, family is a civil partnership between husband and wife who act as caretaker. marital assets are civil partnership assets. A family in taking legal actions against the joint assets must act with the consent of the husband and wife, and without mutual consent the transaction is null and void by law. Every transaction that is carried out by the husband or wife on behalf of the family and used for the benefit of the family becomes jointly and severally husband's and wife's responsibility if there is a loss from the transaction. A family civil partnership is not a legal entity because is does not fulfill the formal requirements as an Indonesian legal entity.
\end{abstract}

\section{Kata Kunci: $\quad$ Abstrak}

Keluarga; Subyek Penelitian ini bertujuan untuk menganalisis status keluarga sebagai subyek Hukum; Harta hukum, apakah suami-isteri sebagai keluarga dianggap satu subyek hukum atau Bersama. masing-masing menjadi subyek hukum yang mandiri. Pembahasan difokuskan pada keluarga sebagai subyek hukum dalam pengurusan harta bersama perkawinan. Penelitian ini menyimpulkan bahwa keluarga dianggap satu subyek hukum dalam kaitannya sebagai subyek pemilikan harta bersama. Dalam lalu lintas hukum, keluarga merupakan sebuah persekutuan dengan suami-isteri yang bertindak sebagai pengurusnya. Harta bersama adalah harta persekutuan, keluarga dalam melakukan perbuatan hukum terhadap harta bersama harus bertindak atas persetujuan suami dan isteri, tanpa persetujuan satu sama lain transaksi tersebut tidak sah dan batal demi hukum. Setiap transaksi yang dilakukan suami atau isteri atas nama keluarga dan digunakan untuk kepentingan keluarga, maka suami-isteri bertanggungjawab secara tanggung renteng apabila terjadi kerugian yang ditimbulkan dari transaksi tersebut. Persekutuan keluarga bukan persekutuan yang berbadan hukum karena tidak memenuhi syarat formil sebagai badan hukum Indonesia.

Published in Media Iuris. Publish

Copyright (C) 2021 Perwitiningsih dan Rikardo Simarmata.

\section{Pendahuluan}

Keluarga lahir akibat salah satu dari kodrat manusia dengan adanya ketertarikan antara laki-laki dan perempuan. Perkawinan antara laki-laki dan perempuan dalam membentuk keluarga sangat berpengaruh terhadap 
Perwitiningsih: Status Keluarga Sebagai...

kepentingan perseorangan maupun kelompok. ${ }^{1}$ Dari segi kepentingan pribadi perseorangan, baik laki-laki maupun perempuan masing-masing perlu untuk memenuhi kebutuhan jasmani dan rohaninya. Dari segi kepentingan sosial, dalam hidup bermasyarakat terdapat norma yang harus dipatuhi agar tercipta keadaan tertib dan teratur. Selain itu, manusia juga merupakan mahluk ciptaan Tuhan Yang Maha Esa dan terdapat hukum Tuhan yang harus ditaati. ${ }^{2}$

Laki-laki dan perempuan yang telah melakukan perkawinan akan membawa konsekuensi terhadap hubungan antara suami dan isteri, hubungan antara orang tua dengan anaknya (apabila ada) dan juga membawa konsekuensi terhadap harta kekayaan dalam perkawinan. ${ }^{3}$ Dalam hal pengurusan harta kekayaan dalam perkawinan, wanita bersuami dianggap tidak cakap hukum menurut ketentuan Kitab Undang-Undang Hukum Perdata (KUH Perdata). Tindakan isteri terkait harta kekayaan pribadi maupun harta kekayaan perkawinan tidak akan membawa akibat hukum tanpa kuasa atau bantuan dari suaminya. ${ }^{4}$

Ketentuan seperti ini muncul karena KUH Perdata Perancis (tempat asal mula KUH Perdata Indonesia) menganut sistem patrilineal dalam hukum keluarganya, selain itu juga untuk menghindari prinsip satu kapal dengan dua nahkoda. Ketentuan tersebut kemudian dicabut dengan Surat Edaran Mahkamah Agung Nomor 3 Tahun 1963 yang menyatakan bahwa ketentuan Pasal 108 dan 110 KUH Perdata yang mengatur tentang ketidakcakapan istri yang bersuami sudah tidak berlaku, kemudian dibuat ketentuan Undang-Undang Nomor 1 Tahun 1974 tentang Perkawinan atau dikenal dengan UUP yang berprinsip bahwa baik suami maupun istri sama-sama cakap melakukan perbuatan hukum. ${ }^{5}$

Seorang isteri yang menurut KUH Perdata sebelumnya dianggap tidak cakap hukum untuk bertindak melaksanakan hak dan kewajibannya, ${ }^{6}$ kemudian

\footnotetext{
${ }^{1}$ Abdul Ghofur Anshori, ‘Orientasi Nilai Filsafat Hukum Keluarga: Refleksi Undang-Undang Nomor 1 Tahun 1974 tentang Perkawinan' (2006) 18 Mimbar Hukum.[2-3].

2 ibid.[10].

${ }^{3}$ Salim H. S., Pengantar Hukum Perdata Tertulis (BW) (Sinar Grafika 2014).[73-74].

${ }^{4}$ J. Andy Hartanto, Hukum Harta Kekayaan Perkawinan (Laksbang Grafika 2012).[7].

${ }^{5}$ Munir Fuady, Konsep Hukum Perdata (Rajawali 2015).[7-8].

${ }^{6}$ Pasal 110 Kitab Undang-Undang Hukum Perdata.
} 
diberikan hak dan kedudukan yang sama dengan suami dalam UUP. ${ }^{7}$ Wanita yang bersuami berhak memiliki dan melakukan tindakan hukum atas harta bersama maupun harta pribadi atau harta bawaan yang diperolehnya dari orang tuanya, baik melalui hadiah, hibah, warisan dan sebagainya. ${ }^{8}$ Suami dan istri merupakan dua komponen yang sama pentingnya dalam menjalankan fungsi keluarga. Keduanya sama-sama memiliki hak yang legal dalam semua urusan rumah tangga dan dalam mengembangkan profesi masing-masing tanpa hambatan dari satu sama lain. ${ }^{9}$

Bersatunya suami dan isteri menjadi sebuah keluarga dan adanya pengakuan bahwa pasangan suami-isteri merupakan subyek hukum yang sama-sama cakap melakukan perbuatan hukum meskipun terikat perkawinan, ${ }^{10}$ membuat suami-isteri ini saling bekerjasama dalam mengusahakan harta mereka dengan mendirikan sebuah badan usaha, misalnya berupa Perseroan Terbatas. Dalam hal pendirian Perseroan Terbatas, suami-isteri yang tidak membuat perjanjian pisah harta dianggap sebagai satu subyek hukum, sehingga mereka tidak bisa mendirikan Perseroan Terbatas kecuali terdapat subyek hukum lain yang juga menjadi penyetor modal. ${ }^{11}$

Berdasarkan uraian di atas kemudian timbul pertanyaan apakah suamiisteri tanpa perjanjian pisah harta ini dianggap menjadi satu subyek hukum atau masing-masing sebagai subyek hukum mandiri dalam melakukan perbuatan hukum sebagai sebuah keluarga? Paper ini akan membahas dan menganalisis status keluarga sebagai subyek hukum harta bersama perkawinan di Indonesia. Menganalisis bagaimana suami-isteri menjalankan hak dan kewajiban mereka

\footnotetext{
${ }^{7}$ Pasal 31 ayat (1) Undang-Undang Nomor 1 Tahun 1974 tentang Perkawinan.

${ }^{8}$ Muhammad Daud Ali, Islam untuk Disiplin Ilmu Hukum, Sosial dan Politik (Departemen Agama RI 1996).[31-32].

${ }^{9}$ Endang Sumiarni, Kedudukan Suami Istri dalam Hukum Perkawinan (Wonderful Publshing Company 2004).[12-13].

${ }^{10}$ Ninik Darmini, ‘Kajian Yuridis Terhadap Tidak Dicantumkannya Bentuk Harta dalam Perkawinan Pada Perjanjian Kredit dan Perjanjian Penjaminannya Menurut Hukum di Indonesia', (2018) Disertasi Program Doktor Ilmu Hukum Universitas Gadjah Mada Yogyakarta. [269].

11 Risma Permatasari, 'Akibat Hukum Perseroan Terbatas Yang Didirikan Oleh Suami Istri Tanpa Perjanjian Kawin’ (2018) 14 Mimbar Keadilan.[229].
} 
sebagai satu kesatuan keluarga dalam lalu lintas hukum serta bagaimana tanggungjawab terhadap pihak ketiga. Keluarga yang dibahas dalam paper ini dibatasi pada keluarga yang lahir karena adanya perkawinan antara seorang pria dengan seorang wanita, mengingat fokus penelitian ini adalah keluarga sebagai subyek hukum dalam pengurusan harta bersama perkawinan dan masingmasing perkawinan memiliki "harta bersama" yang dikelola dan berada di bawah kekuasaannya sendiri.

\section{Subyek Hukum}

Subyek hukum (person) adalah istilah yang dipakai untuk menunjuk pendukung hak dan kewajiban dalam hukum. ${ }^{12}$ Apeldoorn berpendapat bahwa subyek hukum merupakan segala sesuatu yang mempunyai kewenangan untuk melakukan suatu perbuatan hukum atau dalam bahasa belanda disebut persoonlijkheid (kewenangan hukum). ${ }^{13}$ Istilah "kewenangan" dan "kecakapan" mempunyai arti yang berbeda dalam hukum. Kewenangan hukum merupakan kewenangan untuk memiliki hak dan kewajiban dalam hukum. Kewenangan bertindak adalah kewenangan khusus yang dimiliki oleh subyek hukum tertentu untuk melakukan perbuatan hukum tertentu. ${ }^{14}$

Manusia adalah pendukung utama hak dan kewajiban, jadi manusia diakui sebagai subyek hukum. ${ }^{15}$ Dilihat dari sejarah, manusia tidak begitu saja diakui sebagai subyek hukum, dahulu dikenal adanya manusia yang bukan subyek hukum sehingga tidak mempunyai hak dan kewajiban, yaitu manusia budak. ${ }^{16}$ Menurut lembaga perbudakan, secara yuridis manusia budak dianggap sebagai benda dan masuk dalam harta kekayaan seseorang. Sebenarnya tidak ada ketentuan undang-undang Indonesia yang secara tegas mengatakan bahwa

\footnotetext{
12 J. Satrio, Hukum Pribadi (Citra Aditya Bakti 1999).[16].

${ }^{13}$ Apeldoorn dalam Endra Agus Setiawan, [et.al.], 'Konsep dan Kriteria Kecakapan Bertindak Bagi Penyandang Disabilitas Autisme Menurut Perspektif Hukum Perdata Indonesia' (2018) Jurnal

14 ibid.[169].

${ }^{15}$ J. Satrio, Loc.Cit.

${ }^{16}$ Sudikno Mertokusumo, Mengenal Hukum Suatu Pengantar (Cahaya Atma Pustaka 2010).[93].
} Selat Vol. 5 No. 2.[171]. 
manusia adalah subyek hukum. Kesimpulan ini di dapat dari ketentuan dalam kata-kata Pembukaan dan Pasal 27, 28, 29 Undang-Undang Dasar 1945 serta Pasal 1 dan 3 KUH Perdata bahwa di Indonesia tidak dikenal lagi perbudakan, maka dapat dikatakan bahwa semua manusia pada dasarnya adalah subyek hukum. ${ }^{17}$

Setiap manusia pada dasarnya memiliki kewenangan hukum akan tetapi tidak setiap manusia dapat dianggap cakap bertindak untuk melakukan perbuatan hukum. KUH Perdata tidak memberikan klasifikasi yang jelas mengenai bagaimana seseorang dianggap cakap hukum. Parameter yang digunakan untuk menentukan kriteria kecakapan hukum adalah dengan melihat kebalikan dari Pasal 1330 KUH Perdata yang menentukan bahwa orang yang belum dewasa (belum cukup umur), orang yang berada di bawah pengampuan dan wanita bersuami adalah orang yang tak cakap untuk membuat persetujuan. Ketentuan mengenai ketidakcakapan wanita bersuami sudah tidak berlaku lagi karena telah dicabut dengan Surat Edaran Mahkamah Agung Nomor 3 Tahun 1963.

Pasal 330 KUH Perdata menentukan bahwa orang yang dianggap belum cukup umur adalah yang belum mencapai usia 21 (duapuluh satu) tahun dan belum pernah melakukan perkawinan sebelumnya. Melihat ketentuan Pasal 1330 dan 330 KUH Perdata mengenai ketidakcakapan seseorang, maka dapat diartikan bahwa seseorang baru dianggap cakap membuat persetujuan apabila dia telah berusia dewasa (mencapai duapuluh satu tahun) atau telah pernah menikah dan tidak berada di bawah pengampuan. ${ }^{18}$

Ketentuan mengenai batas usia kedewasaan itu sendiri ada beragam. Selain batas usia 21 (duapuluh satu) tahun sebagaimana diatur dalam KUH Perdata, ada juga ketentuan lain yang menentukan batas usia dewasanya, misalnya adalah batas usia 18 (delapanbelas) tahun untuk bekerja, ${ }^{19} 17$ (tujuhbelas) tahun untuk memilih, ${ }^{20} 15$ (limabelas) tahun untuk menjadi saksi di Pengadilan, ${ }^{21} 19$

\footnotetext{
${ }^{17}$ J. Satrio. Op.Cit.[18].

${ }^{18}$ Endra Agus Setiawan. Op.Cit.[168].

${ }^{19}$ Pasal 1 angka 26 Undang-Undang Nomor 13 Tahun 2003 tentang Ketenagakerjaan.

${ }^{20}$ Pasal 28 Undang-Undang Nomor 3 Tahun 1999 tentang Pemilihan Umum.

${ }^{21}$ Pasal 145 Herzien Indlandsch Reglement (HIR) (S.1941-44).
} 
Perwitiningsih: Status Keluarga Sebagai...

(Sembilanbelas) tahun bagi laki-laki dan 16 (enambelas) tahun bagi perempuan untuk melangsungkan perkawinan. ${ }^{22}$

Selain manusia yang diakui sebagai subyek hukum secara kodrati, ada badan-badan atau perkumpulan tertentu yang juga diakui eksistensinya sebagai subyek hukum, yaitu Badan Hukum. Badan atau perkumpulan yang diakui sebagai badan hukum misalnya Perseroan Terbatas, yayasan, koperasi, termasuk juga Negara, wakaf, gereja, dan lain-lain. Sebagai subyek hukum badan hukum diperlakukan layaknya manusia atau memiliki status yang dipersamakan dengan manusia, badan hukum dapat mempunyai harta kekayaan sendiri, dapat turut serta dalam lalu lintas hukum melalui pengurusnya, serta dapat menggugat dan digugat di pengadilan. ${ }^{23}$

Kehadiranbadanhukumsebagaisubyekhukumselainmanusiamenimbulkan perdebatan diantara para ahli ilmu hukum yang kemudian melahirkan beberapa teori tentang badan hukum. Diantaranya adalah sebagai berikut:

a. Teori fiksi, tokoh yang mempelopori teori ini adalah Friedrich Carl von Savigny pada awal abad 19. Menurut teori ini, badan hukum adalah suatu fiksi atau abstraksi belaka, bukan sesuatu yang konkrit. Sesuatu yang sebenarnya tidak ada tetapi manusia membuat badan hukum sebagai bayangan untuk menerangkan suatu hal kemudian diperlakukan sama dengan manusia. Badan hukum hanyalah ciptaan Negara atau pemerintah yang tidak dapat melakukan perbuatan hukum sendiri, sehingga dalam melakukan perbuatan hukum diwakili oleh manusia sebagai wakil-wakilnya. ${ }^{24}$

b. Teori organ, teori yang dikemukakan oleh Otto von Gierke ini menganggap bahwa badan hukum bukanlah sesuatu yang abstrak melainkan sesuatu yang riil atau benar-benar ada. Badan hukum sama halnya seperti manusia yang dapat membentuk dan menyatakan kehendak sendiri dengan perantara organorgannya, yaitu pengurus dan anggota badan hukum tersebut. ${ }^{25}$

c. Teori kekayaan bersama, teori yang dikemukakan oleh Rudolf von Jhering ini menganggap badan hukum bukan sebuah abstraksi dan bukan organisme. Badan hukum adalah kumpulan manusia. Kepentingan badan hukum adalah kepentingan manusia, hak dan kewajiban badan hukum adalah hak dan

\footnotetext{
${ }^{22}$ Pasal 7 Undang-Undang Nomor 1 Tahun 1974 tentang Perkawinan.

${ }^{23}$ Siti Nurjanah \& Antony Antony, 'Kajian Hukum Perdata Tentang Pertanggungjawaban Perseroan Terbatas Sebagai Subyek Hukum', (2017) 17 Journal of Judicial Review.[136].

${ }^{24}$ Mulhadi, Hukum Perusahaan Bentuk-Bentuk Badan Usaha di Indonesia (Ghalia Indonesia 2010).[77].

25 Dyah Hapsari Prananingrum, 'Telaah Terhadap Esensi Subjek Hukum: Manusia Dan Badan Hukum', (2014) 8 Refleksi Hukum: Jurnal Ilmu Hukum.[87-88].
} 
kewajiban anggota bersama-sama, harta kekayaan badan adalah milik bersama seluruh anggota dan mereka bertanggungjawab bersama. ${ }^{26}$

d. Teori kenyataan yuridis, teori ini dipelopori oleh E.M. Meijers kemudian diikuti oleh Paul Scholten. Teori ini menganggap bahwa badan hukum adalah realitas yang riil dan konkrit walaupun tidak bisa diraba tetapi suatu kenyataan yuridis. Badan hukum adalah wujud riil yang sama dengan manusia. Persamaan badan hukum dan manusia hanya terbatas sampai bidang hukum saja. ${ }^{27}$

Menurut Pasal 1653 KUH Perdata, Badan Hukum dibagi menjadi tiga macam; yaitu Badan Hukum yang "diadakan” oleh pemerintah/kekuasaan umum seperti Daerah Provinsi/Kabupaten dan bank yang didirikan oleh Negara. Badan Hukum yang "diakui" oleh pemerintah/kekuasaan umum seperti organisasi-organisasi keagamaan. Badan hukum yang “didirikan” untuk suatu maksud tertentu yang tidak bertentangan dengan undang-undang dan kesusilaan seperti Perseroan Terbatas.

Menurut para ahli suatu badan atau perkumpulan bisa dikatakan sebagai badan hukum harus memenuhi beberapa unsur, yaitu badan tersebut mempunyai harta kekayaan yang terpisah dari harta kekayaan pendiri dan anggotanya. Pemisahan kekayaan merupakan persyaratan mutlak karena kekayaan inilah yang akan digunakan untuk menunaikan tanggungjawab dalam bertindak sebagai subyek hukum. Unsur lain yang harus dimiliki badan tersebut adalah mempunyai tujuan tertentu yang tidak bertentangan dengan perundangundangan yang ada. Badan tersebut juga harus memiliki kepentingan sendiri dalam lalu lintas hukum. Adanya organisasi kepengurusan juga menjadi salah satu unsur penting yang harus ada. ${ }^{28}$

Selain unsur materil sebagaimana disebutkan di atas, suatu badanjuga harus memenuhi unsur formil agar dapat diakui sebagai badan hukum, yaitu; secara tegas dinyatakan dalam peraturan perundang-undangan yang mengaturnya, secara tegas dinyatakan dalam akta pendiriannya, ada pengesahan dari Kementerian Hukum dan Hak Asasi Manusia, dipertegas dalam yurisprudensi

\footnotetext{
${ }^{26}$ Mulhadi, Op.Cit.[78].

27 ibid.

${ }^{28}$ Dyah Hapsari Prananingrum, Op.Cit.[83-84].
} 
Perwitiningsih: Status Keluarga Sebagai...

dan menurut kebiasaan diakui sebagai badan hukum. ${ }^{29}$ Perbedaan suatu perkumpulan atau badan yang diakui sebagai badan hukum dengan bukan badan hukum adalah badan hukum mempunyai harta kekayaan dan tanggungjawab yang terpisah antara para anggota dengan perkumpulannya, sehingga apabila perkumpulan mempunyai hutang, maka semua hutang perkumpulan dilunasi dengan harta perkumpulan tidak sampai harta pribadi anggotanya. Sedangkan perkumpulan yang bukan badan hukum pelunasan hutang bisa sampai pada harta pribadi para anggotanya. ${ }^{30}$

\section{Persekutuan Keluarga}

Keluarga adalah unit terkecil dalam masyarakat yang terdiri dari suamiisteri, atau suami, isteri dan anaknya, atau ayah dan anaknya, atau ibu dan anaknya. ${ }^{31}$ Definisi keluarga menurut sejumlah ahli adalah sebagai kesatuan sosialekonomi paling kecil di masyarakat yang menjadi landasan dasar atas semua institusi, berupa kelompok primer terdiri dari dua atau lebih orang yang memiliki hubungan darah, hubungan interpersonal, hubungan yang tercipta karena adanya perkawinan dan adopsi. ${ }^{32}$ Tujuan dari membentuk keluarga adalah demi mewujudkan kesejahteraan lahir dan kebahagiaan batin anggota keluarganya. ${ }^{33}$ Sejahtera dalam arti dibentuk atas dasar perkawinan yang sah, kebutuhan jasmani dan rohani terpenuhi, bertakwa kepada Tuhan Yang Maha Esa dan memiliki hubungan seimbang antar anggota keluarga dan masyarakat. ${ }^{34}$

Dilihat dari definisi dan tujuannya keluarga merupakan suatu persekutuan, yaitu kesatuan orang-orang yang mempunyai kepentingan sama terhadap suatu

\footnotetext{
${ }^{29}$ Mulhadi, Op.Cit.[75].

${ }^{30}$ Dyah Hapsari Prananingrum. Op.Cit.[130].

${ }^{31}$ Pasal 1 angka 6 Undang-Undang Nomor 52 Tahun 2009 tentang Perkembangan Kependudukan dan Pembangunan Keluarga, lihat juga pada Pasal 1 angka 1 Peraturan Pemerintah Nomor 21 Tahun 1994 tentang Penyelenggaraan Pembangunan Keluarga Sejahtera.

${ }^{32}$ Herien Puspitawati, Gender dan keluarga Konsep dan Realita di Indonesia (IPB Press 2019).[85].

${ }^{33}$ Pasal 11 ayat (2) Undang-Undang Nomor 52 Tahun 2009 tentang Perkembangan Kependudukan dan Pembangunan Keluarga.

${ }^{34}$ Herien Puspitawati. Loc.Cit.
} 
usaha tertentu, ${ }^{35}$ Namun tujuan dari pembentukan keluarga tidak semata-mata untuk menjalankan usaha atau mencari keuntungan saja akan tetapi untuk mencapai kebahagiaan, kesejahteraan dan kemanfaatan bagi seluruh anggota keluarganya. Anggota keluarga merupakan istilah yang lazim digunakan untuk menyebut orang-orang atau peserta yang menjadi bagian dari sebuah keluarga.

Menurut kepustakaan hukum, istilah persekutuan sama dengan perseroan dan perserikatan. Ketiga istilah tersebut digunakan sebagai terjemahan bahasa belanda "maatschap" dan "vennootschap" yang dalam bahasa aslinya berarti kawan dan sekutu. ${ }^{36}$ Kitab Undang-Undang Hukum Perdata (KUH Perdata) memberikan definisi maatschap dalam Pasal 1618 yaitu suatu persetujuan dua orang atau lebih yang saling mengikatkan diri untuk memasukkan sesuatu (inbreng) dalam persekutuan dengan tujuan untuk berbagi keuntungan yang didapat. Namun dalam keluarga, hasil dari pemasukan tidak hanya berupa keuntungan saja tapi juga kemanfaatan bagi seluruh anggota keluarga.

Persekutuan didirikan atas dasar perjanjian konsensual, yaitu perjanjian yang terjadi karena ada kesepakatan dari para pihak sebelum ada tindakan penyerahan barang, meskipun belum ada pemasukan (inbreng) persekutuan sudah dianggap ada selama para sekutu sudah sepakat untuk mendirikannya. Akta pendirian persekutuan dapat dibuat berupa akta otentik maupun akta di bawah tangan, tidak diwajibkan untuk adanya pendaftaran atas pendirian tersebut. ${ }^{37}$ Dapat dikatakan keluarga juga lahir dari perjanjian karena perkawinan merupakan sebuah perjanjian, akan tetapi perjanjian disini bersifat formil artinya perjanjian tersebut lahir dan mengikat secara sah apabila syarat-syarat dan formalitas perkawinan sebagaimana diatur dalam UUP jo. Peraturan Pemerintah Nomor 9 Tahun 1975 tentang Pelaksanaan Undang-Undang Nomor 1 Tahun 1974 tentang Perkawinan telah terpenuhi. ${ }^{38}$

\footnotetext{
${ }^{35}$ Mulhadi. Op.Cit.[35].

36 ibid.[35].

37 ibid.[38].

${ }^{38}$ Trusto Subekti, 'Sahnya Perkawinan Menurut Undang-Undang Nomor 1 Tahun 1974 Tentang Perkawinan Ditinjau Dari Hukum Perjanjian', (2010) 10 Jurnal Dinamika Hukum. [338].
} 
Perkawinan yang sah harus memenuhi dua hal, yaitu harus sah dilakukan berdasar hukum agama dan kepercayaan masing-masing, ${ }^{39}$ selain itu juga perkawinan tersebut harus dicatat menurut peraturan perundang-undangan yang berlaku. ${ }^{40}$ Kedua syarat tersebut harus terpenuhi agar perkawinan diakui sah oleh agama maupun oleh Negara. Secara yuridis pencatatan perkawinan merupakan bukti bahwa suatu perkawinan telah terjadi, yaitu dengan ditunjukkannya kutipan akta perkawinan. Melalui pencatatan perkawinan ini Negara menjamin kepastian hukum, memberikan pengakuan dan perlindungan hukum terhadap keluarga tersebut serta dalam hal mengikat pihak ketiga. ${ }^{41}$

Pencatatan perkawinan bagi mereka yang Muslim dan melakukan perkawinan menurut agama Islam dilakukan oleh Kantor Urusan Agama (KUA), sedangkan bagi mereka yang melakukan perkawinan menurut agama dan kepercayaan selain Islam pencatatan perkawinan dilakukan oleh Kantor Catatan Sipil. ${ }^{42}$ Pencatatan perkawinan dilakukan dengan menandatangani akta perkawinan yang dilaksanakan sesaat setelah perkawinan dilangsungkan, dengan ditandatanganinya akta perkawinan, maka perkawinan tersebut telah resmi tercatat. ${ }^{43}$ Sebuah keluarga yang didirikan berdasar ikatan perkawinan, harus dicatat dalam akta perkawinan agar bisa menjadi bukti autentik dan memberikan perlindungan hukum terhadap anggota keluarga atas hak dan kewajiban yang ditimbulkan setelah adanya perkawinan. Berdirinya persekutuan keluarga terhitung sejak ditandatanganinya akta perkawinan ini.

\section{Hubungan Internal Anggota Keluarga}

Sebagaimana telah dijelaksan dalam latar belakang, bahwa semenjak berlakunya UUP, para anggota keluarga dalam hal ini suami-isteri memiliki

\footnotetext{
${ }^{39}$ Pasal 2 ayat (1) Undang-Undang Nomor 1 Tahun 1974 tentang Perkawinan.

${ }^{40}$ Pasal 2 ayat (2) Undang-Undang Nomor 1 Tahun 1974 tentang Perkawinan.

${ }^{41}$ Trusto Subekti. Op.Cit. [338].

${ }^{42}$ Pasal 2 Peraturan Pemerintah Nomor 9 Tahun 1975 tentang Pelaksanaan Undang-Undang Nomor 1 Tahun 1974 tentang Perkawinan.

${ }^{43}$ Pasal 11 Peraturan Pemerintah Nomor 9 Tahun 1975 tentang Pelaksanaan Undang-Undang Nomor 1 Tahun 1974 tentang Perkawinan.
} 
hak dan kedudukan yang seimbang dan hubungan yang sederajat dalam rumah tangga ${ }^{44}$ Masing-masing berhak untuk melakukan perbuatan hukum. ${ }^{45}$ Perbuatan hukum dimaksud misalnya dalam hal pengurusan dan pengalihan harta kekayaan perkawinan. Dikenal dua macam harta kekayaan dalam perkawinan, yaitu harta bersama dan harta bawaan atau harta pribadi. Harta bersama merupakan semua harta yang dihasilkan suami dan/atau isteri selama dalam ikatan perkawinan yang sah. ${ }^{46}$ Harta bawaan merupakan harta yang diperoleh suami atau isteri dari hadiah atau warisan. ${ }^{47}$

Harta bersama merupakan harta persekutuan keluarga, keluarga dari perkawinan yang satu dengan perkawinan yang lain merupakan sebuah persekutuan yang masing-masing berdiri sendiri dan memiliki harta bersama mereka sendiri. Harta bersama dari masing-masing keluarga berada dibawah kekuasaan keluarga masing-masing dengan pasangan suami-isteri yang bertindak sebagai pengurus secara bersama-sama. ${ }^{48}$ Mengenai pemasukan (inbreng) suamiisteri dalam harta bersama, Sebagaimana pemasukan (inbreng) dalam pesekutuan perdata yang dimaksud dalam Pasal 1618 KUH Perdata tidak selalu berupa uang, bisa juga berupa barang, tenaga dan pikiran, hal serupa berlaku juga dalam pemasukan (inbreng) suami-isteri dalam harta bersama perkawinan. Menurut $M$ Yahya Harahap, tidak dipermasalahkan siapapun yang mendapat pemasukan atau penghasilan dalam keluarga, semua harta benda yang didapat selama dalam ikatan perkawinan dianggap sebagai pemasukan dan milik bersama suami-isteri. ${ }^{49}$

Harta yang telah dimiliki suami atau isteri sebelum dilangsungkannya perkawinan tidak dihitung sebagai pemasukan (inbreng) dalam harta bersama karena harta tersebut termasuk ke dalam harta pribadi atau harta bawaan. Kecuali penghasilan atas harta bawaan tersebut yang diperoleh setelah perkawinan

${ }^{44}$ Pasal 31 ayat (1) Undang-Undang Nomor 1 Tahun 1974 tentang Perkawinan.

${ }^{45}$ Pasal 31 ayat (2) Undang-Undang Nomor 1 Tahun 1974 tentang Perkawinan.

${ }^{46}$ Pasal 35 ayat (1) Undang-Undang Nomor 1 Tahun 1974 tentang Perkawinan.

${ }^{47}$ Pasal 35 ayat (2) Undang-Undang Nomor 1 Tahun 1974 tentang Perkawinan.

${ }^{48}$ Pasal 36 ayat (1) Undang-Undang Nomor 1 Tahun 1974 tentang Perkawinan.

${ }^{49}$ M. Yahya Harahap dalam H. M. Anshary MK, Hukum Perkawinan Indonesia Masalah-Masalah Krusial (Pustaka Pelajar 2010).[134-137]. 
Perwitiningsih: Status Keluarga Sebagai...

dilangsungkan, baru dapat dihitung sebagai pemasukan (inbreng) dalam harta bersama. ${ }^{50}$ Termasuk juga dalam harta bawaan adalah harta yang diperoleh dari hadiah atau hibah dan warisan. ${ }^{51}$ Harta bawaan berada di bawah penguasaan masing-masing dan pemiliknya memiliki hak penuh untuk melakukan perbuatan hukum atas harta tersebut..$^{52}$ Suami-isteri tidak membutuhkan persetujuan satu sama lain dalam melakukan transaksi terhadap harta pribadinya.

Antara suami-isteri tidak diperbolehkan melakukan perjanjian jual beli, ${ }^{53}$ perjanjian saling menghibahkan ${ }^{54}$ dan perjanjian perburuhan. ${ }^{55}$ Ketentuan larangan pengalihan hak antara suami-isteri dimaksudkan untuk melindungi hak kreditur atau pihak ketiga yang mengadakan perjanjian baik dengan pihak suami maupun isteri dan menjadikan harta bersama mereka sebagai barang jaminan. ${ }^{56}$ Lagipula sia-sia bagi suami atau isteri sebagai debitur yang banyak hutangnya kemudian menghibahkan harta bendanya yang bernilai kepada pasangan kawinnya agar harta benda itu selamat dari penyitaan dan pelelangan oleh pengadilan sebagai pembayaran hutang, sebab harta benda yang dihibahkan itu merupakan harta bersama yang tidak akan bebas dari penyitaan dan pelelangan untuk membayar hutang. ${ }^{57}$

Mengenai kepengurusan dalam keluarga, UUP mengatur dalam Pasal 31 ayat (3) yang menyatakan bahwa suami adalah kepala keluarga dan isteri sebagai ibu rumah tangga. Bukan berarti pasal ini diskriminatif atau bias gender karena membedakan peran suami-isteri. Pasal ini merupakan bagian dari lima pasal dari Bab VI tentang hak dan kewajiban suami istri. Apabila pasal-pasal dan ayat-ayat dibaca dengan harmonisasi akan menghasilkan makna kepala keluarga yang

\footnotetext{
${ }^{50}$ ibid.[136].

${ }^{51}$ Pasal 35 ayat (2) Undang-Undang Nomor 1 Tahun 1974 tentang Perkawinan.

${ }^{52}$ Pasal 36 ayat (2) Undang -Undang Nomor 1 Tahun 1974 tentang Perkawinan.

${ }^{53}$ Pasal 147 Kitab Undang-Undang Hukum Perdata.

${ }^{54}$ Pasal 1678 Kitab Undang-Undang Hukum Perdata.

${ }^{55}$ Pasal 1601 Kitab Undang-Undang Hukum Perdata.

${ }^{56}$ Revita Mala Siregar, 'Studi Komparasi Tentang Jual Beli Antara Suami Istri Menurut Hukum Islam dan KUH Perdata Pasal 1467', (2018) Skripsi, Fakultas Syariah dan Ilmu Hukum Institut Agama Islam Negeri PadangSidimpuan.[58].

${ }^{57}$ Suryodiningrat, Perikatan-Perikatan Berdasarkan Sumber Perjanjian (Tarsito 1980).[59].
} 
dimaksud dalam ayat ini hakikatnya tidak lebih dari sebuah simbolik ketika sebuah keluarga diartikan sebagai sebuah lembaga atau organisasi yang memerlukan seseorang sebagai pimpinan..$^{58}$

\section{Keluarga dalam Lalu Lintas Hukum}

Keluarga dalam melakukan perbuatan hukum yang berkaitan dengan harta bersama, suami-isteri sebagai pengurus harus bertindak atas persetujuan satu sama lain. ${ }^{59}$ Penjualan atau pengalihan harta benda yang merupakan harta bersama harus didasari atas persetujuan suami-isteri, ${ }^{60}$ sebagai contoh misalnya dalam penjualan harta bersama berupa tanah hak milik. Pasal 39 ayat (1) huruf d Peraturan Pemerintah Republik Indonesia Nomor 24 Tahun 1997 tentang Pendaftaran Tanah yang menyatakan bahwa Pejabat Pembuat Akta Tanah (PPAT) wajib menolak membuat akta jual beli tanah apabila salah satu pihak bertindak atas dasar suatu surat kuasa mutlak yang pada hakikatnya berisikan perbuatan hukum pemindahan hak. Boedi Harsono memberi penjabaran atas pasal tersebut dalam hal misalnya mengenai harta bersama/gono-gini, suami-isteri bisa melakukan perbuatan hukum atas persetujuan satu sama lain. Apabila dalam sertipikat hanya dicantumkan nama suami atau isteri, PPAT harus menanyakan apakah tanah yang bersangkutan harta pribadi atau harta bersama. ${ }^{61}$

Salah satu syarat materiil dalam jual beli hak milik atas tanah adalah penjual merupakan pihak yang berwenang. Selain usianya harus dewasa dan cakap menurut peraturan perundang-undangan, kedudukan dan status penjual adalah pihak yang berhak menjual tanah tersebut. Apabila tanah hak milik dimiliki lebih dari satu orang, maka yang berhak menjual tanah adalah mereka yang memiliki tanah itu secara bersama-sama dan dilarang dijual oleh satu orang saja. Pemilikan bersama tanah hak milik dapat terjadi karena pewarisan atau dibeli

${ }^{58}$ Mukhtar Zamzami, Perempuan dan Keadilan dalam Hukum Kewarisan Indonesia (Kencana Prenada Media Group 2013). [183-184].

${ }^{59}$ Pasal 36 ayat (1) Undang-Undang Nomor 1 Tahun 1974 tentang Perkawinan.

${ }^{60}$ Putusan Mahkamah Agung RI Nomor 2690 K/Pdt/1985 tertanggal 3 November 1986.

${ }^{61}$ Boedi Harsono, Hukum Agraria Indonesia: Sejarah Pembentukan Undang-Undang Pokok Agraria, Isi dan Pelaksanaannya (Djambatan 2008).[509]. 
Perwitiningsih: Status Keluarga Sebagai...

secara patungan atau didapat dari hibah, ${ }^{62}$ bisa juga menjadi milik bersama karena adanya percampuran harta dalam perkawinan.

Hak milik atas tanah sebagai harta bersama/gono-gini, walaupun dalam sertipikat hanya tertulis satu nama yaitu suami atau isteri saja, maka pada pembuatan akta pengalihan haknya PPAT harus mensyaratkan kehadiran dari pasangan kawinnya untuk ikut menandatangani akta pengalihan hak sebagai bukti akan persetujuannya terhadap pengalihan hak tersebut atau apabila kawan kawinnya tidak dapat hadir dalam penandatanganan akta pengalihan hak, maka dapat digantikan dengan persetujuan tertulis yang dibuat lebih dahulu sebelum akta pengalihan hak ditandatangani. ${ }^{63}$

Apabila transaksi tersebut kemudian diketahui tanpa persetujuan satu sama lain, maka transaksi tersebut tidak sah dan batal demi hukum. Sertipikat tanah atas transaksi jual beli tanah yang tidak sah tersebut juga tidak memiliki kekuatan hukum. ${ }^{64}$ Selain dalam hal jual beli tanah, apabila keluarga ingin melakukan perbuatan hukum lain berupa pengalihan hak atas tanah harta bersama juga harus mendapat persetujuan bersama suami-isteri. Pengalihan hak atas tanah dimaksud meliputi hibah, tukar menukar, pemberian dengan wasiat dan perbuatan hukum lain yang bermaksud memindahkan hak pemilikan atas tanah. ${ }^{65}$

Persetujuan bersama suami-isteri dalam transaksi terkait harta bersama keluarga tidak hanya dibutuhkan dalam hal pengalihan hak atas tanah saja, persetujuan ini juga diperlukan ketika salah satu suami/isteri atau keduanya atas nama keluarga akan mengajukan perjanjian kredit dan harta bersama dijadikan sebagai jaminan hutangnya. Tidak adanya persetujuan dari keduanya menyebabkan perjanjian kredit yang dibuat atas nama keluarga tersebut batal demi hukum. Hal ini dikarenakan salah satu syarat sahnya perjanjian yaitu suatu

\footnotetext{
${ }^{62}$ Fredik Mayore Saranaung, ‘Peralihan Hak Atas Tanah Melalui Jual Beli Menurut Peraturan Pemerintah Nomor 24 Tahun 1997', (2017) 6 Lex Crimen.[18-19].

${ }^{63}$ Mustofa, Tuntunan Pembuatan Akta-akta PPAT (KaryaMedia 2014).[57].

${ }^{64}$ Putusan Mahkamah Agung RI Nomor 2691 PK/Pdt/1996 tertanggal 18 September 1998, lihat juga pada Putusan Mahkamah Agung RI Nomor 701 K/pdt/1997 tertanggal 24 Maret 1999 dan Putusan Mahkamah Agung RI Nomor 263 K/Sip/1976 tertanggal 13 November 1978.

${ }^{65}$ Harun Al-Rasyid, Sekilas Tentang Jual Beli Tanah (Berikut Peraturan-Peraturannya) (Ghalia Indonesia 1987).[50].
} 
sebab yang halal sebagaimana dimaksud dalam Pasal 1320 KUH Perdata tidak terpenuhi. Obyek yang dijadikan jaminan dalam perjanjian kredit adalah harta bersama suami-isteri, untuk menjaminkan atau mengalihkan obyek tersebut harus atas persetujuan semua pihak yang berhak atas harta tersebut, pihak yang berhak atas harta bersama yaitu suami dan isteri. ${ }^{66}$

Pendapat lain mengatakan bahwa perbuatan menjaminkan harta bersama atas suatu hutang tanpa persetujuan suami atau isteri mengakibatkan perjanjian tersebut dapat dibatalkan karena syarat sahnya perjanjian sebagaimana diatur dalam Pasal 1320 KUH Perdata yaitu tentang kecakapan seseorang dalam membuat perjanjian tidak terpenuhi. ${ }^{67}$ Demi keamanan kreditor dalam memberikan fasilitas kredit terhadap keluarga, apalagi sulit untuk memastikan apakah harta tersebut merupakan harta pribadi atau harta bersama suami-isteri, maka sebaiknya kreditor meminta persetujuan dari suami-isteri secara bersama-sama dalam pembuatan perjanjian kredit dan pengikatan jaminannya. ${ }^{68}$

Dari penjelasan-penjelasan di atas telah jelas bahwa suami-isteri tidak dapat dipisahkan ketika melakukan transaksi yang berkaitan dengan harta bersama. Bahkan keluarga yang hanya terdiri dari suami dan isteri saja tidak bisa mendirikan Perseroan terbatas. Pasal 7 ayat (1) Undang-Undang Nomor 40 Tahun 2007 tentang Perseroan Terbatas mengatur bahwa Perseroan Terbatas harus didirikan minimal dua orang atau lebih, sedangkan keluarga yang hanya terdiri dari suami-isteri saja dianggap sebagai satu subyek hukum. Hal ini dikarenakan Perseroan Terbatas merupakan persekutuan modal, suami-isteri meskipun terdiri dari dua orang akan tetapi modal mereka berasal dari satu sumber yang sama yaitu harta bersama. Keluarga baru bisa mendirikan Perseroan Terbatas apabila terdapat anggota keluarga atau saudara atau orang lain sebagai penyetor modal dengan sumber modal yang berbeda dari sumber modal suami-isteri (harta bersama) tersebut. ${ }^{69}$

${ }^{66}$ Putusan Mahkamah Agung RI Nomor 209 K/pdt/2000 tertanggal 26 Februari 2002.

${ }^{67}$ Abraham Lombogia, 'Pembebanan Hak Tanggungan atas Harta Bersama Suami dan Isteri dihubungkan dengan UU No. 1 tahun 1974', (2014) 2 Lex Privatum.[89].

${ }^{68}$ ibid. [88].

${ }^{69}$ Risma Permatasari, Loc.Cit. 
Keluarga yang lahir dari adanya perkawinan campuran tidak bisa menjadi subyek hukum hak milik atas tanah. Perkawinan campuran merupakan perkawinan yang dilakukan oleh dua orang yang salah satunya adalah Warga Negara Indonesia dan lainnya adalah Warga Negara Asing yang tunduk pada hukum Negara yang berbeda. ${ }^{70}$ Hak milik atas tanah hanya dapat dimiliki oleh Warga Negara Indonesia, ${ }^{71}$ sedangkan dalam perkawinan campuran terdapat anggota keluarga yang berkewarganegaraan asing. Sebagaimana telah dijelaskan sebelumnya, bahwa setelah perkawinan berlangsung semua harta yang didapat setelahnya menjadi milik bersama, harta milik suami adalah milik isteri dan begitu sebaliknya.

Warga Negara Asing yang melakukan perkawinan campuran dengan Warga Negara Indonesia dapat memperoleh hak milik atas tanah sebagai akibat dari percampuran harta dan kepemilikan kolektif suami-isteri tersebut dan hal ini bertentangan dengan Pasal 21 ayat (1) Undang-Undang Nomor 5 Tahun 1960 tentang Peraturan Dasar Pokok-Pokok Agraria. Oleh karena itu dalam ayat (3) di pasal yang sama diatur bahwa Warga Negara Asing yang memperoleh hak milik karena percampuran harta perkawinan wajib melepaskan haknya itu dalam jangka waktu satu tahun. Apabila dalam jangka waktu tersebut hak miliknya belum juga dilepaskan, maka hak tersebut hapus karena hukum dan tanahnya jatuh kepada Negara. ${ }^{72}$

Keluarga dapat menyimpangi ketentuan-ketentuan sebagaimana disebut di atas dan permasalahan yang ditimbulkan akibat adanya percampuran harta itu dapat dihindari dengan dibuat perjanjian perkawinan pisah harta. Perjanjian perkawinan dibuat tertulis pada saat atau sebelum atau selama dalam ikatan perkawinan dengan disahkan oleh pegawai pencatat perkawinan atau Notaris. ${ }^{73}$

\footnotetext{
${ }^{70}$ Pasal 57 Undang-Undang Nomor 1 Tahun 1974 tentang Perkawinan.

${ }^{71}$ Pasal 21 ayat (1) Undang-Undang Nomor 5 Tahun 1960 tentang Peraturan Dasar PokokPokok Agraria.

${ }^{72}$ Pasal 21 ayat (3) Undang-Undang Nomor 5 Tahun 1960 tentang Peraturan Dasar PokokPokok Agraria.

${ }^{73}$ Pasal 29 ayat (1) Undang-Undang Nomor 1 Tahun 1974 tentang Perkawinan jo. putusan MK Nomor 69/PUU-XIII/2015.
} 
Perjanjian ini berlaku sejak perkawinan dilangsungkan kecuali ditentukan lain dalam perjanjian perkawinan. ${ }^{74}$

Dengan dibuatnya perjanjian perkawinan pisah harta, maka suami-isteri tidak perlu memenuhi kewajiban adanya persetujuan satu sama lain dalam melakukan transaksi mengenai hartanya, karena harta yang diperoleh merupakan harta pribadi masing-masing dan berada di bawah kekuasaan masing-masing. Suami-isteri diperbolehkan mendirikan Perseroan Terbatas karena sumber modal mereka terpisah. Selanjutnya Warga Negara Indonesia yang melakukan perkawinan campuran dengan Warga Negara Asing tetap bisa memiliki tanah dengan status hak milik karena di dalam hartanya tidak ada percampuran harta yang membuat Warga Negara Asing mendapat tanah dengan status hak milik.

\section{Pembagian Harta Bersama dan Tanggungjawab Terhadap Pihak Ketiga}

Ketentuan mengenai pembagian besar porsi dan perolehan masing-masing anggota keluarga dalam harta bersama tidak diatur dalam undang-undang kecuali jika pembagian tersebut dikaitkan dengan bubarnya perkawinan. Pada saat masih dalam ikatan perkawinan dan menjadi keluarga, pasangan suami-isteri cenderung tidak memikirkan atau membahas mengenai harta bersama mereka, setiap keluarga selalu menginginkan keluarganya utuh dan perkawinan tersebut diharapkan bertahan untuk selamanya. Oleh sebab itu setelah terjadi perceraian, sering terjadi keributan mengenai pembagian harta bersama dan masing-masing mengklaim bahwa harta tersebut adalah bagian dari haknya. ${ }^{75}$

Perceraian membawa akibat terhadap harta bersama yang diperoleh suamiisteri selama dalam ikatan perkawinan. Saat terjadi perceraian, maka harta bersama harus dibagi antara mantan suami-isteri tersebut. Menurut Pasal 37 UUP apabila terjadi perceraian, maka harta benda perkawinan diatur menurut hukumnya masing-masing. Kalimat hukum masing-masing disini menunjukkan

${ }^{74}$ Pasal 29 ayat (3) Undang-Undang Nomor 1 Tahun 1974 tentang Perkawinan jo. putusan MK Nomor 69/PUU-XIII/2015.

${ }^{75}$ Etty Rochaeti, 'Analisis Yuridis Tentang Harta Bersama (Gono Gini) Dalam Perkawinan Menurut Pandangan Hukum Islam Dan Hukum Positif', (2015) 28 Jurnal Wawasan Yuridika.[651]. 
Perwitiningsih: Status Keluarga Sebagai...

masih terdapat pluralisme hukum yang berlaku dalam penyelesaian sengketa pembagian harta benda perkawinan, yaitu berlaku hukum adat dan KUH Perdata dalam penyelesaian sengketa di Pengadilan Negeri dan berlaku hukum Islam bagi mereka yang menyelesaikan sengketanya di Pengadilan Agama. ${ }^{76}$

Menurut Kompilasi Hukum Islam (KHI), suami-isteri yang bercerai masingmasing berhak separoh bagian atas harta bersama sepanjang tidak ditentukan lain dalam perjanjian perkawinan. ${ }^{77}$ hal serupa juga diatur dalam Pasal $128 \mathrm{KUH}$ Perdata yang mengatakan bahwa setelah tali perkawinan suami-isteri putus, maka harta kekayaan bersama dibagi dua antara suami dan isteri atau antara para ahli waris tanpa mempersoalkan dari pihak mana harta tersebut berasal. Mengenai pembagian harta bersama perkawinan setelah terjadi perceraian, Mahkamah Agung telah memberikan putusan yang kaidah hukumnya menyatakan bahwa pembagian harta guna kaya antara suami-isteri masing-masing mendapat $50 \%$ (limapuluh persen). ${ }^{78}$

Apabila salah satu suami atau isteri meninggal dunia, maka separoh harta bersama menjadi bagian dari pasangan yang masih hidup terlama. ${ }^{79}$ Sebagaimana Putusan Mahkamah Agung Republik Indonesia Nomor 3764/Pdt/1992 tanggal 30 Maret 1992 yang pertimbangan hukumnya menyatakan bahwa pembagian harta bersama akibat kematian suami atau isteri adalah $1 / 2$ (setengah) bagian dari harta bersama akan menjadi hak janda atau duda yang masih hidup terlama dan $1 / 2$ (setengah) bagian lagi akan menjadi harta warisan yang akan dibagikan antara janda atau duda itu dan anak-anaknya. ${ }^{80}$

Menurut KUH Perdata, pasca bubarnya harta persatuan, suami dapat ditagih atas hutang dan harta persatuan sepenuhnya tanpa mengurangi hak untuk menuntut kembali separoh bagian atas hutang itu kepada isteri atau ahli

\footnotetext{
${ }^{76}$ Julius Martin Saragih \& Herni Widanarti Yunanto, ‘Pertanggungjawaban Hutang-Hutang Persatuan Setelah Putusnya Perkawinan’, (2017) 6 Diponegoro Law Journal.[9].

${ }_{77}$ Pasal 97 Kompilasi Hukum Islam.

${ }^{78}$ Putusan Mahkamah Agung RI Nomor 392 K/Sip/1969 Tertanggal 30 Agustus 1969.

${ }^{79}$ Pasal 96 ayat (1) Kompilasi Hukum Islam. 1976.

${ }^{80}$ Lihat juga Putusan Mahkamah Agung RI Nomor 44 K/Sip/1975 Tertangal 9 September
} 
warisnya. ${ }^{81}$ Setelah pembagian dan pemisahan harta persatuan kreditur tidak bisa menuntut suami-isteri untuk membayar hutang yang dibuat oleh pihak lain dari suami atau isteri sebelum terjadinya perkawinan. Hutang-hutang tersebut tetap menjadi tanggungan masing-masing yang membuatnya atau para ahli warisnya. Hal tersebut tidak mengurangi hak pihak yang satu untuk meminta ganti rugi kepada pihak lain atau ahli warisnya. ${ }^{82}$

Bagi Warga Negara Indonesia yang beragama Islam dan mengajukan perkaranya ke Pengadilan Agama, dalam memutus perkara harta bersama Hakim akan merujuk pada ketentuan Kompilasi Hukum Islam (KHI). Persoalan hutang-piutang bersama, KHI tidak menyebutkan bagian secara pasti mengenai pertanggungan hutang bersama akan tetapi KHI mengatur bahwa pertanggungjawaban atas hutang suami atau hutang isteri dibebankan pada harta masing-masing. Pertanggungjawaban atas hutang yang digunakan untuk kepentingan bersama keluarga, dibebankan pada harta bersama. Apabila harta bersama tidak mencukupi untuk membayar hutang, maka pertanggungjawaban dibebankan pada harta suami dan apabila harta suami tidak mencukupi pertanggungjawaban dibebankan pada harta isteri..$^{83}$

Percampuran harta benda dalam harta persatuan tidak hanya berupa aktiva akan tetapi juga termasuk di dalamnya adalah berupa pasiva. Artinya jika selama perkawinan diperoleh sejumlah harta tertentu, maka harta tersebut menjadi pendapatan (aktiva) keluarga itu. Begitu juga jika terdapat beban-beban hutang (pasiva), maka hutang itu menjadi hutang keluarga ${ }^{84}$ Hal serupa juga menjadi pertimbangan Majelis Hakim Pengadilan Agama dalam menafsirkan Pasal 35 ayat (1) Undang-Undang Perkawinan yang menyatakan bahwa semua harta yang diperoleh selama dalam ikatan perkawinan adalah harta bersama. Harta yang dimaksud dalam pasal ini tidak hanya berupa keuntungan saja tetapi juga dalam bentuk kerugian seperti halnya hutang. Semua hutang-hutang yang terjadi

\footnotetext{
${ }^{81}$ Pasal 130 Kitab Undang-Undang Hukum Perdata.

${ }^{82}$ Pasal 131 Kitab Undang-Undang Hukum Perdata.

${ }^{83}$ Pasal 93 Kompilasi Hukum Islam.

${ }^{84}$ Julius Martin Saragih \& Herni Widanarti Yunanto. Op.Cit.[7].
} 
Perwitiningsih: Status Keluarga Sebagai...

selama masih dalam ikatan perkawinan merupakan hutang keluarga dan menjadi tanggungjawab bersama suami-isteri secara tanggung renteng. ${ }^{85}$

Adapun syarat suatu hutang dapat dikategorikan sebagai hutang bersama adalah hutang tersebut dibuat untuk kepentingan keluarga bukan untuk kepentingan lain, atas kesepakatan dan persetujuan bersama suami-isteri serta hutang tersebut dibuat selama suami-isteri masih menjadi keluarga dan terikat dalam perkawinan. ${ }^{86}$ Hutang demi kepentingan keluarga dimaksud misalnya hutang atau pengeluaran untuk kebutuhan rumah tangga, untuk biaya pendidikan anak, memperbaiki rumah tinggal bersama, modal usaha dan lain-lain yang digunakan untuk mensejahterakan anggota keluarga. ${ }^{87}$

Dalam beberapa perkara mengenai pembagian harta bersama di pengadilan baik di tingkat pertama maupun ditingkat banding ada kalanya Hakim memutuskan untuk tidak membagi hutang bersama akan tetapi membebankan hutang tersebut kepada salah satu pihak suami atau isteri saja. Penyelesaiannya yaitu dengan tidak membagi harta bersama, artinya harta bersama yang harusnya dibagi separoh bagian masing-masing untuk suami-isteri tersebut tidak dibagi, akan tetapi diberikan sepenuhnya kepada suami atau isteri sebagai debitor yang bertanda tangan atas hutang bersama tersebut..$^{88}$ Tidak celah sedikitpun sehingga dapat menjadi alasan untuk menghilangkan hak dari pihak ketiga sebagai kreditur atas dilunasinya hutang-hutang tersebut meskipun harta bersama telah bubar.

Apabila perjanjian hutang dibuat secara sepihak demi kepentingan pribadi suami atau isteri dan bukan untuk kepentingan bersama keluarga, maka tanggungjawab pelunasan hutangnya dibebankan kepada harta pribadi dan separoh bagian dari harta bersama yang merupakan hak dari pihak suami atau isteri yang membuat hutang tersebut. Hutang pribadi yang terjadi selama dalam masa perkawinan misalnya dalam hal pengeluaran atau hutang yang digunakan

${ }^{85}$ Haryono Daud, \& Ajub Ishak, ‘Pembebanan Hutang Bersama Dalam Putusan Pengadilan Agama Tilamuta', (2020) 1 As-Syams. [34].

${ }^{86}$ St. Ushbul Aini, [et., al.], 'Perlindungan Hukum Terhadap Kreditor Atas Hutang Suami Isteri Yang Tidak Dibebankan Ke Dalam Harta Bersama' (2014) 3 Analisis.[166].

${ }^{87}$ Julius Martin Saragih \& Herni Widanarti Yunanto. Op.Cit.[8].

${ }^{88}$ St. Ushbul Aini, [et., al.]. Loc.Cit. 
untuk membiayai harta dari hibah atau warisan. ${ }^{89}$ Harta pribadi berada di bawah penguasaan masing-masing suami-isteri sepanjang tidak ditentukan lain. ${ }^{90}$ Seperti halnya harta pribadi, hutang pribadi juga menjadi tanggungjawab masing-masing.

\section{Persekutuan Keluarga Bukan Badan Hukum}

Apabila dilihat dari teori kekayaan bersama, yaitu salah satu teori tentang badan hukum yang dikemukakan oleh Rudolf von Jhering sebagaimana telah dibahas sebelumnya, persekutuan keluarga dapat dianggap juga sebagai badan hukum. Badan hukum hanyalah sebuah konstruksi yuridis belaka. Pada dasarnya apa yang menjadi hak, kewajiban, tanggungjawab serta harta kekayaan badan hukum adalah juga milik bersama-sama anggotanya. Hak dan kewajiban persekutuan keluarga adalah hak dan kewajiban suami-isteri sebagai anggota keluarga. Misalnya kewajiban suami-isteri untuk mencatatkan perkawinan ${ }^{91}$ sekaligus menjadi bukti autentik berdirinya persekutuan keluarga tersebut. Harta keluarga adalah harta milik suami-isteri bersama-sama, hutang keluarga adalah hutang bersama suami-isteri. Tanggungjawab atas pelunasan hutang tersebut juga ditanggung bersama-sama oleh suami-isteri. ${ }^{92}$

PendapatScholten mengatakan bahwa sebuahbadanhukumharusmemenuhi tiga unsur, yaitu mempunyai harta kekayaan sendiri yang terpisah, mempunyai tujuan tertentu dan mempunyai alat perlengkapan atau organisasi. ${ }^{93}$ Berdasarkan unsur badan hukum yang disampaikan Scholten tersebut, persekutuan keluarga sudah memenuhi ketiga unsur yang disebutkan. Pertama, Persekutuan keluarga mempunyai "harta bersama" perkawinan yang terpisah dari harta pribadinya. Ketentuan ini disimpulkan dari Pasal 35 dan 36 UUP yang mengatur bahwa harta bersama berbeda dengan harta bawaan, harta bersama baru terhitung sejak suami-isteri terikat perkawinan dan untuk melakukan perbuatan hukum atas

\footnotetext{
${ }^{89}$ Mubarak Fajar, Loc.Cit.

${ }^{90}$ Pasal 35 ayat (2) Undang-Undang Nomor 1 Tahun 1974 tentang Perkawinan.

${ }^{91}$ Pasal 2 Undang-Undang Nomor 1 Tahun 1974 tentang Perkawinan.

${ }^{92}$ Haryono Daud, \& Ajub Ishak, Loc.Cit.

${ }^{93}$ Scholten dalam Dyah Hapsari Prananingrum. Op.Cit.[82].
} 
harta bersama ini harus atas persetujuan bersama suami-isteri. Sedangkan harta bawaan, harta warisan dan hadiah menjadi milik pribadi dan berada di bawah kekuasaan masing-masing suami isteri.

Kedua, persekutuan keluarga memiliki tujuan yaitu membentuk rumah tangga yang bahagia dan kekal berdasarkan Ketuhanan Yang Maha Esa. ${ }^{94}$ Demi mencapai tujuan ini tentunya persekutuan keluarga mempunyai kepentingan yang stabil dan terus menerus untuk mempertahankan persekutuan selamalamanya. Ketiga, walaupun sangat sederhana dengan adanya ketentuan mengenai suami sebagai kepala keluarga dan isteri sebagai ibu rumah tangga dalam Pasal 31 ayat (3) UUP sudah menunjukkan bahwa persekutuan keluarga ini mempunyai organisasi kepengurusan.

Berdasarkan beberapa unsur dan syarat untuk diakui sebagai badan hukum di atas, secara materil persekutuan keluarga sudah bisa dianggap sebagai badan hukum. Akan tetapi untuk bisa diakui sebagai badan hukum di Indonesia tidak cukup hanya memenuhi syarat materil saja, ada syarat formil yang juga harus dipenuhi untuk bisa diakui sebagai badan hukum di Indonesia, misalnya keharusan adanya pengesahan dari Kementrian Hukum dan HAM dan syarat formil lainnya sebagaimana telah dijelaskan sebelumnya dibagian subyek hukum.

\section{Kesimpulan}

Keluarga dianggap sebagai satu subyek hukum dalam kaitannya sebagai subyek kepemilikan harta bersama. Sedangkan dalam lalu lintas hukum, keluarga merupakan sebuah persekutuan. Harta bersama perkawinan adalah harta persekutuan keluarga dan suami-isteri bertindak sebagai pengurus persekutuan dalam mengelola harta bersama. Setiap perbuatan hukum terkait harta bersama, harus atas persetujuan suami-isteri bersama-sama, tanpa adanya persetujuan satu sama lain perbuatan hukum tersebut tidak sah dan batal demi hukum. Setiap transaksi yang dilakukan suami atau isteri atas nama keluarga dan digunakan

\footnotetext{
${ }^{94}$ Pasal 1 Undang-Undang Nomor 1 tahun 1974 tentang Perkawinan.
} 
untuk kepentingan keluarga, maka suami-isteri bertanggungjawab secara tanggung renteng apabila terjadi kerugian yang ditimbulkan dari transaksi tersebut. Persekutuan keluarga bukan persekutuan yang diakui sebagai badan hukum karena tidak memenuhi syarat formil sebagai badan hukum di Indonesia.

\section{Daftar Bacaan}

\section{Buku}

Boedi Harsono, Hukum Agraria Indonesia: Sejarah Pembentukan Undang-Undang Pokok Agraria, Isi dan Pelaksanaannya (Djambatan 2008).

Endang Sumiarni, Kedudukan Suami Istri dalam Hukum Perkawinan (Wonderful Publshing Company 2004).

Harun Al-Rasyid, Sekilas Tentang Jual Beli Tanah (Berikut Peraturan-Peraturannya) (Ghalia Indonesia 1987).

Herien Puspitawati, Gender dan keluarga Konsep dan Realita di Indonesia (IPB Press 2019).

H. M. Anshary MK, Hukum Perkawinan Indonesia Masalah-Masalah Krusial (Pustaka Pelajar 2010).

J. Andy Hartanto, Hukum Harta Kekayaan Perkawinan (Laksbang Grafika 2012).

J. Satrio, Hukum Pribadi (Citra Aditya Bakti 1999).

Muhammad Daud Ali, Islam untuk Disiplin Ilmu Hukum, Sosial dan Politik (Departemen Agama RI 1996).

Mukhtar Zamzami, Perempuan dan Keadilan dalam Hukum Kewarisan Indonesia (Kencana Prenada Media Group 2013).

Mulhadi, Hukum Perusahaan Bentuk-Bentuk Badan Usaha di Indonesia (Ghalia Indonesia 2010).

Munir Fuady, Konsep Hukum Perdata (Rajawali 2015).

Mustofa, Tuntunan Pembuatan Akta-akta PPAT (KaryaMedia 2014).

Salim H. S., Pengantar Hukum Perdata Tertulis (BW) (Sinar Grafika 2014). 
Perwitiningsih: Status Keluarga Sebagai...

Sudikno Mertokusumo, Mengenal Hukum Suatu Pengantar (Cahaya Atma Pustaka 2010).

Suryodiningrat, Perikatan-Perikatan Berdasarkan Sumber Perjanjian (Tarsito 1980).

\section{Jurnal}

Abdul Ghofur Anshori, 'Orientasi Nilai Filsafat Hukum Keluarga: Refleksi Undang-Undang Nomor 1 Tahun 1974 tentang Perkawinan’, (2006) 18 Mimbar Hukum.

Abraham Lombogia, 'Pembebanan Hak Tanggungan atas Harta Bersama Suami dan Isteri dihubungkan dengan UU No. 1 tahun 1974', (2014) 2 Lex Privatum.

Dyah Hapsari Prananingrum, 'Telaah Terhadap Esensi Subjek Hukum: Manusia Dan Badan Hukum’, (2014) 8 Refleksi Hukum: Jurnal Ilmu Hukum.

Endra Agus Setiawan, [et.al.], 'Konsep dan Kriteria Kecakapan Bertindak Bagi Penyandang Disabilitas Autisme Menurut Perspektif Hukum Perdata Indonesia', (2018) Jurnal Selat.

Etty Rochaeti, 'Analisis Yuridis Tentang Harta Bersama (Gono Gini) Dalam Perkawinan Menurut Pandangan Hukum Islam Dan Hukum Positif', (2015) 28 Jurnal Wawasan Yuridika.

Fredik Mayore Saranaung, 'Peralihan Hak Atas Tanah Melalui Jual Beli Menurut Peraturan Pemerintah Nomor 24 Tahun 1997’, (2017) 6 Lex Crimen.

Haryono Daud, \& Ajub Ishak, 'Pembebanan Hhutang Bersama Dalam Putusan Pengadilan Agama Tilamuta’, (2020) 1 As-Syams.

Julius Martin Saragih \& Herni Widanarti Yunanto, 'Pertanggungjawaban HutangHutang Persatuan Setelah Putusnya Perkawinan’, (2017) 6 Diponegoro Law Journal.

Risma Permatasari, 'Akibat Hukum Perseroan Terbatas Yang Didirikan Oleh Suami Istri Tanpa Perjanjian Kawin', (2018) 14 Mimbar Keadilan.

Siti Nurjanah \& Antony Antony, 'Kajian Hukum Perdata Tentang Pertanggungjawaban Perseroan Terbatas Sebagai Subyek Hukum', (2017) 17 Journal of Judicial Review.

St. Ushbul Aini, [et., al.], 'Perlindungan Hukum Terhadap Kreditor Atas Hhutang Suami Isteri Yang Tidak Dibebankan Ke Dalam Harta Bersama', (2014) 3 Analisis. 
Trusto Subekti, 'Sahnya Perkawinan Menurut Undang-Undang Nomor 1 Tahun 1974 Tentang Perkawinan Ditinjau Dari Hukum Perjanjian', (2010) 10 Jurnal Dinamika Hukum.

\section{Skripsi dan Disertasi}

Mubarak Fajar, 'Penyelesaian Hutang-Piutang Dalam Kasus Perceraian Suami Istri Menurut Hukum Perdata di Mahkamah Syari'yah Kelas IA Banda Aceh' (2019) Skripsi, Fakultas Hukum Universitas Muhammadiyah Aceh, Banda Aceh.

Ninik Darmini, 'Kajian Yuridis Terhadap Tidak Dicantumkannya Bentuk Harta dalam Perkawinan Pada Perjanjian Kredit dan Perjanjian Penjaminannya Menurut Hukum di Indonesia', (2018) Disertasi, Program Doktor Ilmu Hukum Universitas Gadjah Mada Yogyakarta.

Revita Mala Siregar, 'Studi Komparasi Tentang Jual Beli Antara Suami Istri Menurut Hukum Islam dan KUH Perdata Pasal 1467', (2018) Skripsi, Fakultas Syariah dan Ilmu Hukum Institut Agama Islam Negeri PadangSidimpuan.

\section{Perundang-undangan}

Kitab Undang-Undang Hukum Perdata.

Herzien Indlandsch Reglement.

Kompilasi Hukum Islam.

Undang-Undang Nomor 1 tahun 1974 tentang Perkawinan. Lembaran Negara Republik Indonesia Tahun 1974 Nomor 1. Tambahan Lembaran Negara republic Indonesia Nomor 3019.

Undang-Undang Nomor 52 Tahun 2009 tentang Perkembangan Kependudukan dan Pembangunan Keluarga. Lembaran Negara Republik Indonesia Tahun 2009 Nomor 161, Tambahan Lembaran Negara Republik Indonesia Nomor 5080 .

Undang-Undang Nomor 5 Tahun 1960 tentang Peraturan Dasar Pokok-Pokok Agraria. Lembaran Negara Tahun 1960 Nomor 104. Tambahan Lembaran Negara Nomor 2043.

Peraturan Pemerintah Nomor 21 Tahun 1994 tentang Penyelenggaraan Pembangunan Keluarga Sejahtera. Lembaran Negara Republik Indonesia Tahun 1994 Nomor 30, Tambahan Lembaran Negara Republik Indonesia Nomor 3553. 
Perwitiningsih: Status Keluarga Sebagai...

Peraturan Pemerintah Nomor 9 Tahun 1975 tentang Pelaksanaan Undang-Undang Nomor 1 Tahun 1974 tentang Perkawinan. Lembaran Negara Republik Indonesia Tahun 1975 Nomor 12, Tambahan Lembaran Negara Republik Indonesia Nomor 3050.

Undang-Undang Nomor 13 Tahun 2003 tentang Ketenagakerjaan. Lembaran Negara Republik Indonesia Tahun 2003 Nomor 39, Tambahan Lembaran Negara Republik Indonesia Nomor 4279.

Undang-Undang Nomor 3 Tahun 1999 tentang Pemilihan Umum. Lembaran Negara Republik Indonesia Tahun 1999 Nomor 23, Tambahan Lembaran Negara Republik Indonesia Nomor 3725.

\section{Yurisprudensi}

Putusan Mahkamah Agung RI Nomor 44 K/Sip/1975 Tertangal 9 September 1976.

Putusan Mahkamah Agung RI Nomor 392 K/Sip/1969 Tertanggal 30 Agustus 1969.

Putusan MK Nomor 69/PUU-XIII/2015 Tertanggal 27 Oktober 2016.

Putusan Mahkamah Agung RI Nomor 209 K/pdt/2000 Tertanggal 26 Februari 2002.

Putusan Mahkamah Agung RI Nomor 2691 PK/Pdt/1996 Tertanggal 18 September 1998.

Putusan Mahkamah Agung RI Nomor 701 K/pdt/1997 Tertanggal 24 Maret 1999.

Putusan Mahkamah Agung RI Nomor 263 K/Sip/1976 Tertanggal 13 November 1978.

Putusan Mahkamah Agung RI Nomor 2690 K/Pdt/1985 Tertanggal 3 November 1986.

How to cite: Perwitiningsih dan Rikardo Simarmata, 'Status Keluarga Sebagai Subyek Hukum dalam Pengurusan Harta Bersama' (2021) Vol. 4 No. 2 Media Iuris. 